\title{
Perancangan Basis Data dan Layanan Akses Berbasis Service Oriented Architecture (SOA) Untuk Dinas Kesehatan Kabupaten Sleman
}

\author{
Inna Yoana Sari Tarigan S, Soedjatmiko, Rudy Hartanto \\ Program Studi Magister Teknologi Informasi, Program Pasca Sarjana Universitas Gadjah Mada \\ Jl. Teknika Utara, Pogung, Sleman, Yogyakarta 55281, Indonesia \\ Email: innatarigan@mti.ugm.ac.id
}

\begin{abstract}
Database Design and Service Oriented Architecture (SOA)-based Access Service for Health Center Transactional Data on Health Office of Sleman District. Health Office of Sleman District is the regional institution that is responsible for organizing health services in the area of Sleman District. In performing these duties and responsibilities, Health Office of Sleman District requires health data and information that is accurate, precise and quick to assist policy decision making process and the health sector by leveraging communication and information technology. This research aims to design a database and SOAbased access service for transactional data center on Health Office of Sleman District. Expected, the results of this research can help Health Office of Sleman District in monitoring public health and to establish interoperability with systems from agencies or other institution.
\end{abstract}

Keywords: Health Office of Sleman District, database, SOA, web service.

\begin{abstract}
Abstrak. Dinas Kesehatan Kabupaten Sleman adalah lembaga regional yang bertanggung jawab untuk mengatur pelayanan kesehatan di wilayah Kabupaten Sleman. Dalam melaksanakan tugas dan tanggung jawabnya, Dinas Kesehatan Kabupaten Sleman memerlukan data kesehatan dan informasi yang akurat, tepat dan cepat untuk membantu proses pengambilan keputusan kebijakan dan sektor kesehatan dengan memanfaatkan teknologi komunikasi dan informasi. Penelitian ini bertujuan untuk merancang sebuah basis data dan layanan akses berbasis SOA untuk pusat data transaksional pada Dinas Kesehatan Kabupaten Sleman. Diharapkan, hasil penelitian ini dapat membantu Dinas Kesehatan Kabupaten Sleman dalam memantau kesehatan masyarakat dan untuk membangun interoperabilitas dengan sistem dari instansi atau lembaga lain.
\end{abstract}

Kata kunci: Dinas Kesehatan Kabupaten Sleman, basis data, SOA, layanan web.

\section{Pendahuluan}

Dinas Kesehatan Kabupaten Sleman merupakan perangkat daerah yang bertanggung jawab terhadap penyelenggaraan pelayanan kesehatan di wilayah Kabupaten Sleman. Pemberlakuan otonomi daerah pada hakekatnya memberikan mandat kepada pemerintah daerah untuk dapat menyelenggarakan pelayanan kesehatan kepada masyarakat dengan sebaik-baiknya. Dengan kewenangan yang telah dimiliki saat ini, seharusnya pemerintah daerah lebih tanggap terhadap kebutuhan kesehatan dari masyarakat yang berada di daerah (Yudatiningsih, 2008). Kabupaten Sleman dalam melaksanakan kebijakan bidang kesehatan tersebut telah mempunyai blue print yang jelas, dalam hal ini untuk mengelola bidang kesehatan ada lima hal yang menjadi fokus pengembangan kesehatan di Kabupaten Sleman, yaitu: (1) perubahan paradigma kesehatan, (2) penataan organisasi, (3) pengembangan sumber daya kesehatan, (4) pembiayaan kesehatan, dan (5) sarana dan prasarana kesehatan. Untuk mendukung pelaksanaan kebijakan 
bidang kesehatan tersebut, diperlukan data dan informasi kesehatan yang akurat, tepat dan cepat untuk membantu proses pengambilan keputusan dan kebijakan bidang kesehatan dengan mendayagunakan teknologi informasi dan komunikasi.

Informasi merupakan hal yang sangat penting bagi Dinas Kesehatan dalam pengambilan keputusan. Informasi ini diperoleh dari kumpulan data atau laporan yang dikirimkan oleh sarana pelayanan kesehatan yang berada dalam wilayah Kabupaten Sleman, baik puskesmas, rumah sakit (pemerintah/swasta), praktik doktek/bidan, apotik, Pondok Bersalin Desa (Polindes), Balai Kesehatan Rakyat. Data di bidang kesehatan sampai saat ini belum tepat waktu dan keakuratnnya pun dipertanyakan. Permasalahan ini sangat klasik karena dari dulu sampai sekarang belum teratasi. Kebutuhaan akan data yang lengkap dan akurat merupakan tuntutan pada era sistem informasi. Dinas kesehatan sebagai leading sector di bidang kesehatan mempunyai tanggung jawab untuk menyediakan layanan data yang berguna dalam perencanaan kesehatan di daerah. Data dan informasi yang tersedia diharapkan dapat berperan sebagai health intelligence. Data dan informasi yang digunakan sebagai health intelligence sangat bermanfaat dalam mengkritisi sebuah keputusan, membuat panduan dalam pengambilan keputusan, membuat interpretasi sebuah fenomena secara detail dan mendalam serta sebagai alert dan reminder untuk masalah-masalah kesehatan potensial. Untuk mewujudkan health intelligence di tingkat kabupaten/kota dibutuhkan integrasi data dan informasi dari seluruh puskesmas dalam kabupaten/kota tersebut sehingga tidak mengalami kesulitan dalam memperoleh informasi yang lengkap, akurat, dan dalam waktu yang singkat.

Berdasarkan uraian permasalahan yang telah dijelaskan sebelumnya, maka diperlukan sebuah basis data terpadu di Dinas Kesehatan yang mengintegrasikan data transaksional puskesmas untuk membantu Dinas Kesehatan Kabupaten Sleman dalam memantau kesehatan masyarakat pada umumnya dan secara khusus menyediakan informasi mengenai puskesmas yang dibutuhkan oleh dinas kesehatan. Data transaksional yang dimaksud dalam penelitian ini adalah data rekam medis pasien, logistik alat-alat kesehatan, pengirimannya, catatan penyimpanan, catatan perpindahan tempat termasuk data tenaga medis di sebuah puskesmas. Diharapkan dari basis data ini, dinas kesehatan dapat memperoleh data atau informasi yang dibutuhkan untuk pengambilan keputusan seperti ketersediaan tenaga medis, peralatan medis, dan obat di sebuah puskesmas. Misal jika pada suatu waktu dari laporan yang tersedia diperoleh keterangan bahwa jumlah tenaga medis atau peralatan medis di suatu puskesmas sudah tidak memadai sehingga harus dikirimkan tambahan peralatan dan tenaga medis (atau pengalihan tenaga medis). Kasus lain misalnya, dengan melihat perbandingan laporan jumlah pasien puskesmas, dinas kesehatan dapat membuat program khusus jika memang diperlukan, seperti misalnya deteksi dini flu burung.

Data yang dihasilkan oleh Dinas Kesehatan Kabupaten Sleman tidak menutup kemungkinan digunakan oleh dinas atau instansi lainnya seperti Pemerintah Daerah, Badan Pusat Statistik, Dinas Kesehatan Provinsi dan Departemen Kesehatan. Dalam kenyataannya dinas atau instansi tersebut memiliki sistem informasi masing-masing, saling independent satu sama lain, dibuat oleh pengembang yang berbeda dan disesuaikan dengan kebutuhan dinas atau instansi yang menggunakannya. Untuk berkomunikasi, sebuah sistem informasi harus mengetahui struktur data dan detail internal sistem informasi yang akan berkomunikasi dengannya, kemudian harus diadakan penyesuaian dan perubahan di kedua belah pihak atau membangun sebuah aplikasi tambahan agar kedua sistem informasi dapat saling berkomunikasi atau bertukar data. Hal ini tentu saja merupakan kendala tersendiri, karena untuk melakukan penyesuaian, kedua belah pihak yang akan berkomunikasi harus bersedia membuka detail sistem informasi yang dimilikinya, hal ini sering sulit dilakukan karena sangat berisiko terhadap keamanan data, sedangkan jika membangun aplikasi tambahan diperlukan waktu dan biaya yang tidak sedikit. Service Oriented Architectute (SOA) merupakan solusi untuk mengatasi permasalahan tersebut.

Manfaat penelitian ini adalah rancangan basis data yang dibuat diharapkan dapat membantu Dinas Kesehatan Kabupaten Sleman untuk meyediakan informasi yang dibutuhkan dalam memantau kesehatan masyarakat pada umumnya dan secara khusus memantau kondisi 
puskesmas. Informasi yang tersedia diharapkan dapat membantu Dinas Kesehatan Kabupaten Sleman dalam mengambil keputusan terkait dengan kesehatan masyarakat. Disamping itu dengan adanya prototype layanan berbasis SOA, dinas atau instansi lain dapat memperoleh data atau informasi yang dimiliki oleh Dinas Kesehatan Kabupaten Sleman dengan lebih mudah.

Penelitian ini bertujuan untuk membuat rancangan basis data dan layanan akses berbasis SOA untuk data transaksional Puskesmas pada Dinas Kesehatan Kabupaten Sleman. Diharapkan hasil penelitian ini, dapat membantu Dinas Kesehatan Kabupaten Sleman dalam memantau kesehatan masyarakat Kabupaten Sleman dan membantu pengambilan keputusan terkait dengan hal tersebut.

\section{Tinjauan Pustaka}

\subsection{Basis Data}

Menurut Connolly dan Carolyn (Robby dan Frans, 2009), basis data adalah koleksi dari data-data yang terkait secara logis dan deskripsi dari data-data tersebut, yang dirancang untuk memenuhi kebutuhan informasi dari suatu organisasi. "Database is a self-describing collection of integrated tables", yang berarti basis data adalah sebuah koleksi data yang menggambarkan integrasi antara tabel yang satu dengan tabel yang lainnya. "Database is a self-describing", disini dijelaskan bahwa struktur data saling terintegrasi dalam suatu tempat yang dikenal sebagai kamus data atau metadata. Jadi, basis data adalah suatu koleksi data yang saling berhubungan secara logis dan menggambarkan integrasi antara suatu tabel dengan tabel lainnya, yang dirancang untuk memenuhi kebutuhan informasi dari suatu organisasi.

\subsection{Integrasi Data}

Integrasi adalah membuat menjadi satu kesatuan yang utuh dengan cara mengumpulkan bagian-bagian yang tersebar. Pengelolaan data yang terpisah dapat menimbulkan duplikasi dan redundansi, yang merupakan potensi terjadinya inkonsistensi data dan mengakibatkan data tidak valid. Oleh sebab itu dibutuhkan integrasi data yang bertujuan untuk membangun keutuhan entitas bisnis melalui pengumpulan elemen-elemen data yang disimpan secara tidak redundan sehingga data-data tersebut bisa digunakan secara konsisten oleh berbagai aplikasi. Sistem integrasi data bertujuan untuk mengharmonisasikan data dari sejumlah sumber ke dalam bentuk yang koheren.

\subsection{SOA (Service Oriented Architecture)}

Service Oriented Architecture (SOA), seperti dapat diamati pada gambar 1, adalah suatu gaya desain yang memandu semua aspek menciptakan dan menggunakan layanan bisnis sepanjang siklus hidup mereka, serta menetapkan dan menyediakan infrastruktur IT yang memungkinkan berbagai aplikasi untuk saling bertukar data dan berpartisipasi dalam proses bisnis tanpa menghiraukan sistem operasi atau bahasa pemrograman yang digunakan aplikasi tersebut. (Eric and Greg, 2004).

SOA merupakan arsitektur yang mendukung integrasi bisnis sebagai layanan yang terhubung dan menjadi jalan menuju inovasi. SOA juga menjadi strategi bisnis berbasis teknologi dan hasil evolusi untuk mengintegrasi berbagai sumber informasi dari sumber kode atau platform yang berbeda-beda. Service dalam lingkup SOA merupakan sekumpulan fungsi, prosedur, atau proses yang akan memberikan respon jika diminta oleh user. SOA adalah sebuah bentuk teknologi arsitektur yang mengikuti prinsip-prinsip service-orientation (berorientasi service) (Erl,2007). Konsep service-orientation ini melakukan pendekatan dengan membagi masalah besar menjadi sekumpulan service kecil yang bertujuan untuk menyelesaikan permasalahan tertentu. SOA tidak terkait dengan suatu teknologi tertentu, tapi lebih kearah pendekatan untuk membangun perangkat lunak yang moduler. 
SOA memiliki sifat-sifat sebagai berikut: (1) SOA bersifat loosely coupled (tingkat ketergantungannya rendah), high interoperable (mudah dioperasikan), reusable (dapat digunakan kembali), dan interoperability (antar platform). (2) Tidak semua kebutuhan komputasi dapat dipenuhi sendiri, terlalu berat dari sisi biaya dan usaha. (3) Independensi diperlukan karena sering kali sebagian fungsionalitas yang diperlukan berada di luar domain kendali pemakai. (4) SOA menggunakan definisi antar muka yang mengenkapsulasi semua implementasi yang ada. (5) SOA bersifat behind the scene, SOA tidak terlihat secara langsung oleh client, SOA dihadapkan pada client melalui antar muka client. (6) SOA merupakan suatu service yang "hanya menunggu" (listen) secara terus-menerus untuk digunakan.

Terdapat beberapa aspek kunci pada prinsip SOA (Thomas, 2005), yaitu: (1) Loose coupling, yaitu bahwa services tersebut mempertahankan sebuah hubungan yang meminimalisasi ketergantungan dan mereka hanya perlu menjaga kesadaran antar satu sama lain. (2) Service contract, services melekat dan taat pada sebuah kesepakatan komunikasi, yang didefinisikan secara kolektif oleh satu atau lebih deskripsi service dan dokumen yang berhubungan. (3) Autonomy, bahwa services mempunyai kendali berdasarkan logika yang dienkapsulasi. (4) Abstraction, di luar apa yang dideskripsikan pada service contract, services menyembunyikan logika dari dunia luar. (5) Reusability, logika terbagi menjadi services dengan tujuan untuk digunakan kembali. (6) Composability, kumpulan dari services dapat dikoordinasikan dan dihimpun untuk membentuk services yang berbeda. (7) Statelessness, services meminimalisasi sifat berpegang teguh pada informasi tertentu untuk sebuah aktivitas. (8) Discoverability, services dirancang dengan sifat yang deskriptif sehingga mereka dapat ditemukan dan ditentukan dengan menggunakan mekanisme-mekanisme penemuan yang ada.

\subsection{Web Service}

Web services adalah sebuah teknik pemrograman di mana sebuah service menggunakan standar-standar berbasis XML dalam menjelaskan antar muka dan protokol yang harus digunakan untuk memanggil service tersebut. Standar-standar tersebut adalah: (1) SOAP (Simple Object Access Protocol): Menjelaskan protokol tentang bagaimana sebuah web service dapat dipanggil. (2) WSDL (Web services Deinition Language): Sebuah format XML yang menjelaskan interface dari sebuah web service (parameter input dan output). (3) UDDI (Universal Description, Discovery and Integration): Sebuah direktori yang berisi daftar web service yang dapat ditemukan dan dipanggil oleh aplikasi lainnya. Dengan standar di atas, web services sangat mendukung implementasi SOA dimana karakteristik SOA seperti loose coupling dan antar muka layanan yang disediakan oleh teknologi web services.

\subsection{SOA dan web service}

Web services seringkali dikaitkan atau bahkan disamakan dengan SOA. Namun sebenarnya keduanya adalah hal yang sangat berbeda. SOA adalah sebuah konsep untuk pengembangan perangkat lunak, sementara web services adalah sebuah aplikasi web yang berinteraksi dengan aplikasi web lainnya untuk pertukaran data. Pembangunan SOA tidak harus menggunakan web services, sebab ada bermacam-macam teknologi lain yang memungkinkan, tapi menggunakan web services untuk membangun sebuah sistem SOA adalah langkah yang baik.

\subsection{Puskesmas}

Kepmenkes nomor 128/Menkes/SK/II/2004 menyatakan bahwa puskesmas merupakan Unit Pelaksana Teknis (UPT) Dinas Kesehatan Kabupaten / Kota yang bertanggung jawab menyelenggarakan pembangunan kesehatan di suatu wilayah. Puskesmas merupakan unit pelaksanan tingkat pertama dan ujung tombak pembangunan kesehatan di Indonesia. 
Agar layanan Puskesmas lebih optimal, Puskesmas menggunakan sebuah sistem informasi yang sering disebut sebagai Sistem Informasi Manajemen Puskesmas (SIMPUS). SIMPUS ini sebenarnya diberikan secara gratis kepada setiap Puskesmas oleh Dinas Kesehatan. Namun dalam kenyataannya, masih banyak Puskesmas yang tidak menggunakan SIMPUS dari Dinas Kesehatan, salah satunya karena Puskesmas tersebut telah menggunakan sistem informasi yang mereka bangun sendiri sebelum SIMPUS didistribusikan oleh Dinas Kesehatan.

Sistem Informasi Manajeman Puskesmas (SIMPUS) memiliki tujuan untuk meningkatkan kualitas manajemen puskesmas secara lebih berhasil guna dan berdaya guna, melalui pemanfaatan secara optimal data dari SP2TP dan informasi lain yang menunjang. Dengan demikian perlu adanya mekanisme pencatatan dan pelaporan yang baik serta formulir yang tersedia cukup dan cara pengisian / pelaporan yang benar.

Adapun pemanfaatan dari Sistem Pencatatan dan pelaporan terpadu (SP2TP) dan informasi lainnya untuk: (1) menunjang proses manajemen tingkat puskesmas, sebagai bahan penyusunan rencana tahunan puskesmas, sebagai bahan penyususnan rencana kerja operasional puskesmas serta bahan untuk pemantauan, evaluasi dan pembianaan. (2) Dinas Kesehatan Kabupaten, sebagai bahan dalam penyusunan rencana tahunan, penilaian kinerja puskesmas berdasarkan beban kerja dan pencapaian hasil kegiatan puskesmas, sebagai bahan untuk pemantauan dan evaluasi pelaksanaan kegiatan program di wilayahnya, serta untuk menentukan prioritas masalah, upaya pemecahan dan tindak lanjutnya, (3) membantu kelancaran perencanaan (P1), penggerakan pelaksanaan (P2) dan pengawasan, pengendalian dan penilaian (P3) program-program serta sebagai masukan dalam diskusi-diskusi musyawarah perencanaan dan pembangunan (Musrenbang).

Adapun format pelaporan yang tersedia di dalam SP2TP meliputi laporan bulanan, laporan bulanan sentinel dan laporan tahunan. Laporan bulanan, meliputi jenis pelaporan sebagai berikut: (1) Laporan bulanan data kesakitan (LB-1), (2) Laporan bulanan data obatobatan (LB-2) atau LPLPO, (3) Laporan bulanan gizi, KIA, Imunisasi, dan pengamatan penyakit menular (LB-3). (4) Laporan bulanan kegiatan puskesmas meliputi kunjungan puskesmas, rawat tinggal, perawatan kesehatan masyarakat, pelayanan medic dasar, kesehatan gigi, pelayanan JPKM, kesehatan sekolah, kesehatan olahraga, PKM, kesehatan lingkungan dan laboratorium (LB-4). Laporan bulanan sentinel, meliputi pelaporan sebagai berikut: (1) Laporan bulanan sentinel penyakit yang dapat dicegah dengan imunisasi, Ispa dan Diare (LB-1S), (2) Laporan bulanan sentinel KIA, gizi, dan penyakit akibat kerja (LB-2S), laporan bulanan ini dibuat oleh puskesmas dengan rawat tinggal. Laporan tahunan, meliputi jenis pelaporan sebagai berikut: (1) Laporan tahunan data dasar puskesmas (LT-1), (2) Laporan tahunana data kepegawaian (LT-2), (3) Laporan tahunan data peralatan (LT-3).

\section{Metodologi Penelitian}

\subsection{Tahapan Penelitian}

Jalannya penelitian yang dilakukan meliputi tahap analisa kebutuhan dan tahap pengembangan sistem. Tahap analisa kebutuhan dilakukan dengan pengumpulan data melalui studi literatur dan survey kondisi data yang tersedia di puskesmas dan kebutuhan informasi Dinas Kesehatan Kabupaten Sleman. Sedangkan tahap pengembangan sistem meliputi: (1) Melakukan analisis terhadap sistem informasi puskesmas dan basis data puskesmas. (2) Membuat rancangan basis data yang dapat mengintegrasikan data transaksional puskemas. (3) Membuat prototype aplikasi untuk mengirimkan data puskesmas ke basis data yang dirancang. (4) Menguji prototype aplikasi dengan dengan mengirimkan data puskesmas ke basis data. (5) Membuat report dan prototype sistem untuk mengakses report tersebut, guna memenuhi kebutuhan informasi Dinas Kesehatan Kabupaten Sleman. (6) Menentukan layanan berbasis SOA untuk mengakses data (informasi) yang dimiliki Dinas Kesehatan. (7) Membuat sample client untuk mengakses layanan yang tersedia (untuk kepentingan pengujian). (8) Melakukan 
pengujian ketersediaan layanan dengan mengakses layanan menggunakan program sample yang telah dibuat.

\subsection{Rancangan Konsep Sistem}

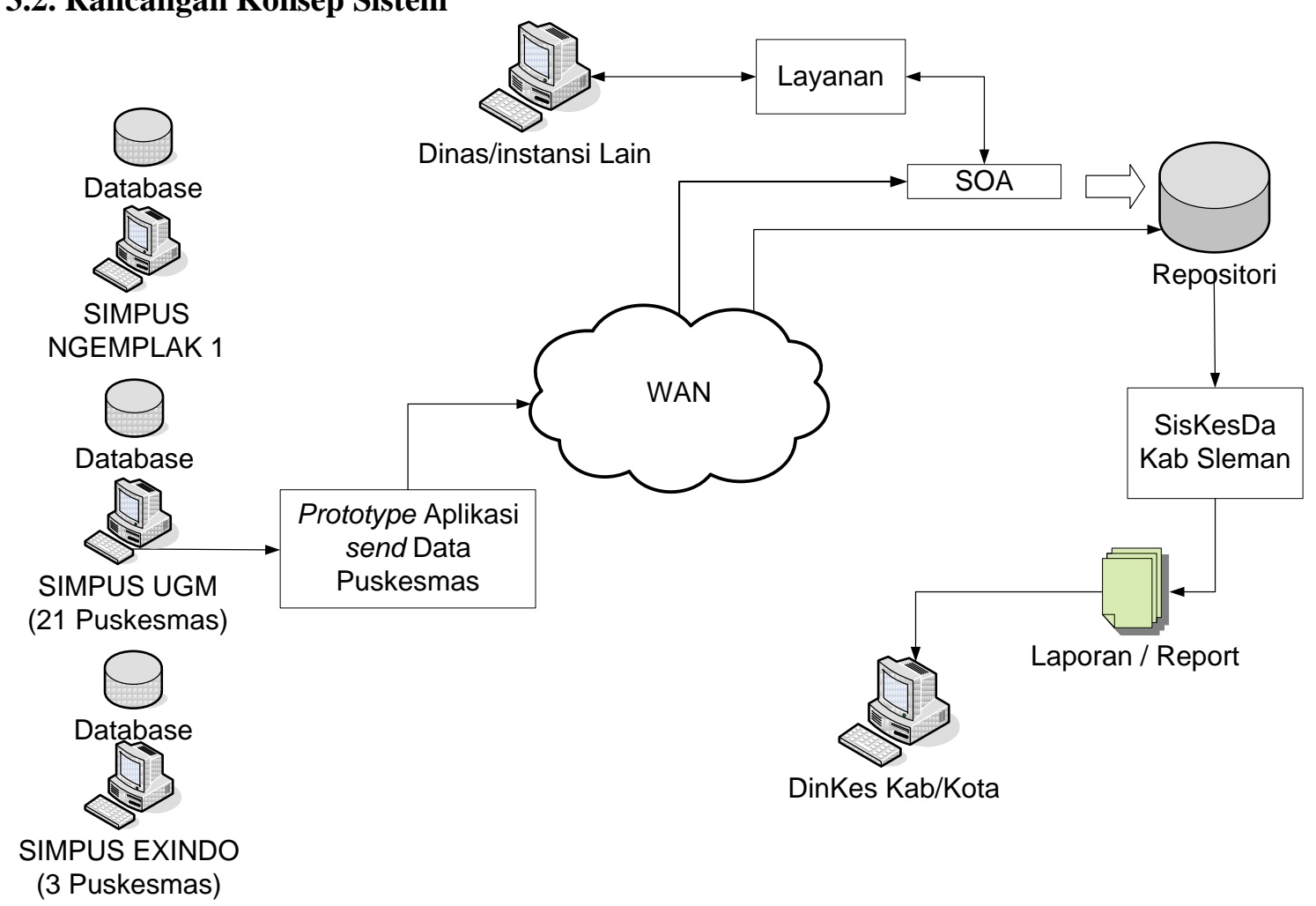

Gambar 1. Konsep sistem

\section{Pengujian dan Pembahasan}

\subsection{Identifikasi sistem informasi dan basis data yang ada di puskesmas dan dinkes saat ini}

Puskesmas yang berada di bawah Dinas Kesehatan Kabupaten Sleman berjumlah 25 puskesmas. Agar layanan Puskesmas lebih optimal, Puskesmas menggunakan sebuah sistem informasi yang sering disebut sebagai Sistem Informasi Manajemen Puskesmas (SIMPUS). Ada tiga jenis SIMPUS yang digunakan oleh Puskesmas di Kabupaten Sleman, yaitu SIMPUS yang dibuat oleh UGM digunakan oleh 21 puskesmas, SIMPUS yang dibuat oleh Exindo digunakan oleh tiga puskesmas, dan SIMPUS yang dikembangkan oleh Sdr.Jojo dan Albert (staf IT Puskesmas) digunakan oleh Puskesmas Ngemplak 1. Sampai saat ini Dinas Kesehatan Kabupaten Sleman belum memiliki sebuah basis data terpadu. Kebutuhan Informasi dipenuhi dari rekap laporan puskesmas dengan menggabungkan satu persatu laporan yang dikirimkan oleh Puskesmas ke Dinas Kesehatan menggunakan program Excel.

Dalam pembuatan penelitian ini akan diambil 3 buah basis data puskesmas sebagai sample data yaitu Puskesmas Gamping I, Puskesmas Ngaglik I dan Puskesmas Depok II. Diagram arus data dari Sistem Informasi Puskesmas yang digunakan oleh 21 Puskesmas dapat diamati pada gambar 2.

Sistem Informasi Puskesmas yang digunakan saat ini, mempermudah proses bisnis yang ada di puskesmas. Sistem Informasi tersebut juga telah dilengkapi oleh laporan-laporan yang dibutuhkan puskesmas, yang dapat diakses dalam format excel maupun pdf. Namun karena Dinas Kesehatan Kabupaten Sleman belum memiliki Sistem Informasi maka Puskesmas mengirimkan laporan LB1, LB2, LB3, LB4 secara manual ke dinas kesehatan dalam format excel. Ada Template khusus yang telah dibuat oleh Dinas Kesehatan Kabupaten Sleman untuk 
laporan-laporan tersebut. Sehingga puskesmas harus berkerja dua kali yaitu menginputkan data ke sistem informasi puskesmas dan mengisi rekap laporan yang akan dikirim ke dinas kesehatan. Untuk puskesmas yang sudah online, Dinas Kesehatan (orang tertentu) dapat mengakases data puskesmas secara online melalui alamat URL puskesmas. Untuk mengolah laporan-laporan dari setiap puskesmas menjadi data terpadu, harus ditambahkan satu persatu secara manual. Oleh sebab itu Dinas Kesehatan membutuhkan sebuah basis data yang dapat mengintegrasikan data-data puskesmas, sehingga sistem pelaporan manual tidak lagi diperlukan. Gambar 3 menggambarkan rancangan proses bisnis setelah basis data dibangun.

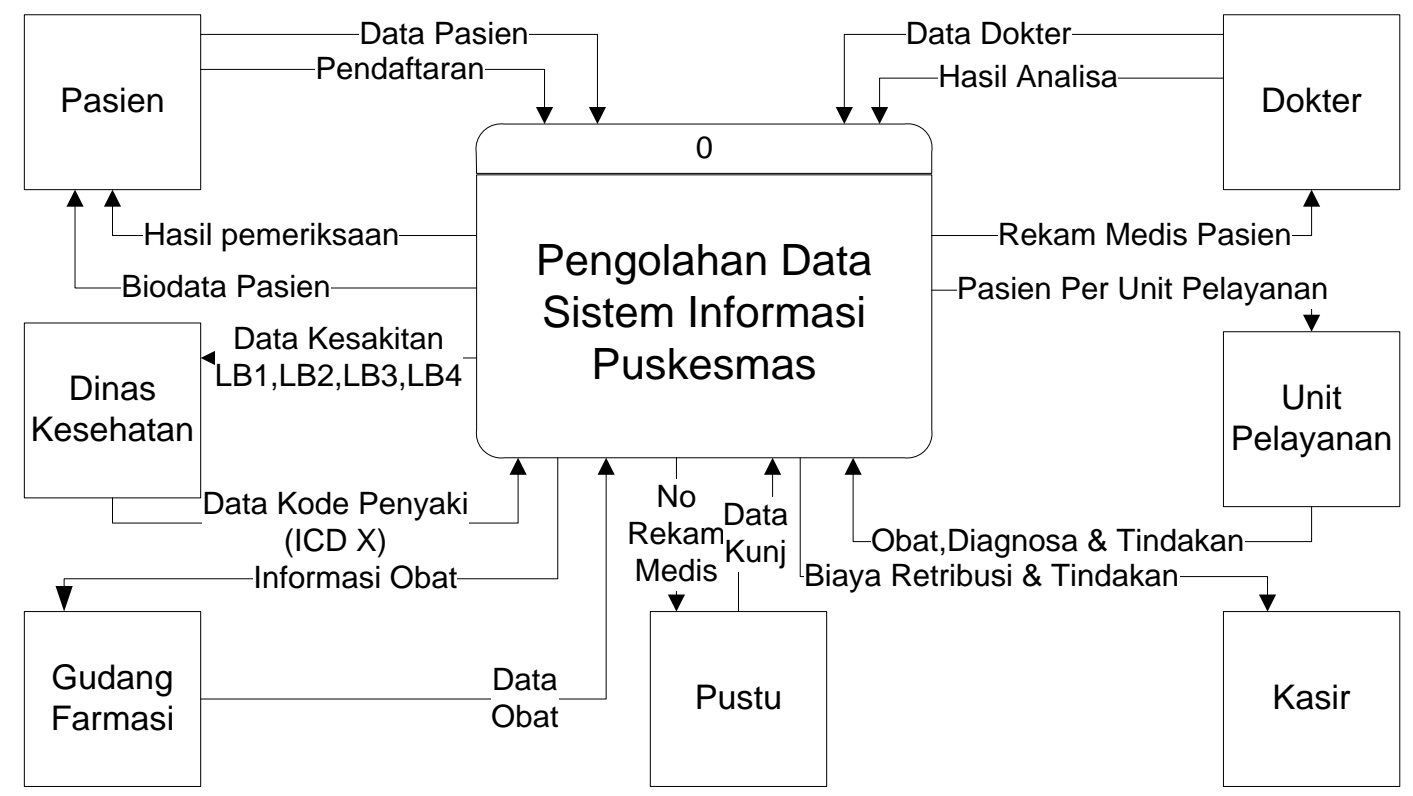

Gambar 2. Diagram arus data sistem informasi puskesmas

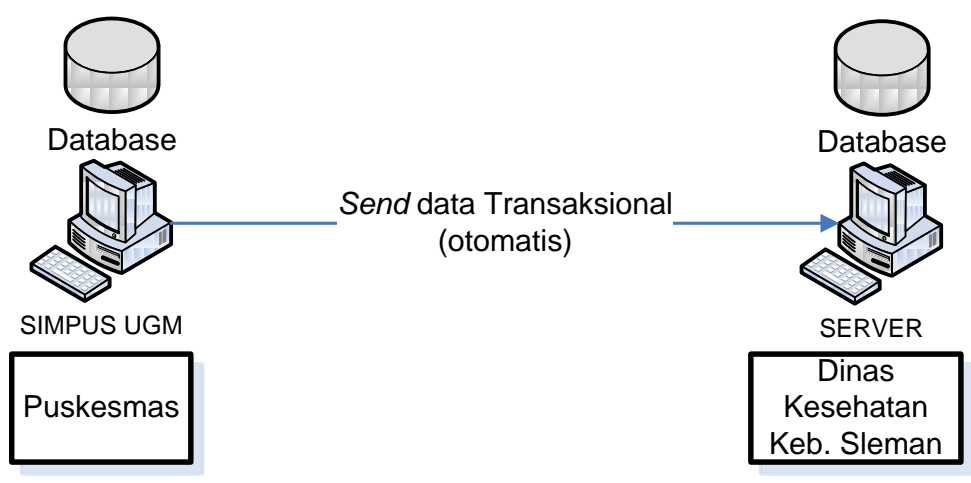

Gambar 3. Rancangan proses bisnis setelah basis data dibangun

Dengan adanya basis data di dinas kesehatan, untuk puskesmas yang telah online (terhubung dengan LAN) dapat mengirimkan data transaksionalnya melalui jaringan LAN yang ada. Puskesmas akan mengirimkan data secara otomatis pada jam tertentu. Dengan memanfaatkan aplikasi Schedule Task yang disediakan oleh Windows, maka pada jam tertentu, akan dieksekusi sebuah script PHP yang akan mengirimkan data transaksional pada hari tersebut ke basis data dinas kesehatan. Untuk puskesmas yang belum online, disediakan sebuah aplikasi yang akan membuat sebuah file (.txt) yang kemudian dapat di-upload di dinas kesehatan.

Hal ini tentu saja akan mengefisienkan pekerjaan yang ada di Puskesmas maupun Dinas Kesehatan, karena Puskesmas tidak perlu lagi bekerja dua kali dalam menginputkan data. Sedangkan untuk dinas kesehatan, dengan adanya basis data ini, dinas kesehatan akan memiliki data puskesmas terkini, karena setiap hari puskesmas akan mengirimkan data ke dinas 
kesehatan. Dari basis data yang tersedia, dapat dibuat laporan-laporan yang dibutuhkan dinas kesehatan dengan lebih fleksibel dan lebih cepat karena data puskesmas tidak perlu ditambahkan satu persatu.

\subsection{Rancangan Basis Data Dinas Kesehatan Kabupaten Sleman}

Berdasarkan hasil analisis sistem informasi dan basis data Sistem Informasi Puskesmas dan kebutuhan informasi/laporan Dinas Kesehatan Kabupaten Sleman, maka dapat dibangun sebuah rancangan basis data untuk Dinas Kesehatan Kabupaten Sleman yang dapat diamati pada gambar 4.

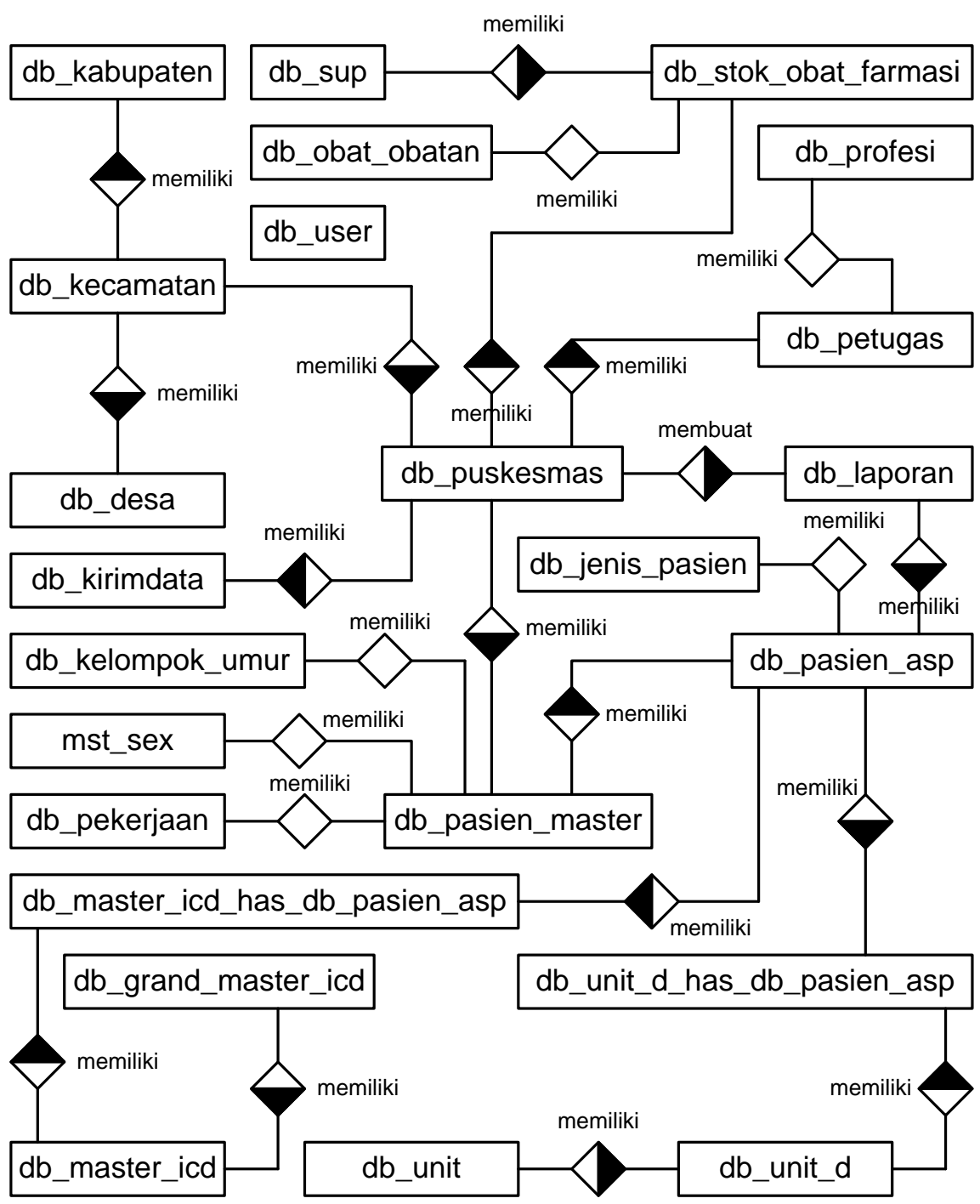

Gambar 4. Entity relationship diagram (ERD)

\subsection{Pembuatan basis data dan prototype sistem}

Rancangan basis data yang dibuat disesuaikan dengan basis data yang digunakan oleh 21 puskesmas yang berada di bawah Dinas Kesehatan Kabupaten Sleman dan informasi yang dibutuhkan oleh Dinas Kesehatan terkait dengan puskesmas yang kemudian diwujudkan dalam bentuk laporan (report). Selanjutnya dari desain tersebut diimplementasikan dan data dari basis data tersebut diperoleh dari puskesmas. Sebuah prototype program untuk mengirimkan data 
secara otomatis dari puskesmas ke dinas kesehatan telah dibuat, sehingga dapat mengirimkan data dari puskesmas ke dinas kesehatan setiap hari sesuai dengan jam yang telah ditentukan. Dinas kesehatan Kabupaten Sleman dapat memantau pengiriman data puskesmas melalui Laporan Pengiriman Data Puskesmas, yang akan menampilkan daftar puskesmas yang telah mengirimkan data pada tanggal tertentu. Jika terjadi sesuatu sehingga mengakibatkan pengiriman data gagal dilakukan, maka puskesmas dapat melakukan import data secara manual dengan prototype aplikasi yang sudah disediakan, kemudian melakukan upload data untuk memasukkan data yang telah di-import tersebut ke dalam basis data dinas kesehatan.

Untuk membantu Dinas Kesehatan Kabupaten Sleman untuk memantau kesehatan masyarakat dan membantu dalam pengambilan keputusan, dibuatkan berbagai laporan (report) yang mengambil data (bersumber) dari basis data yang telah dibagun sebelumnya. Laporanlaporan tersebut dapat diakses melalui prototype sistem berbasis web. Dari prototype ini pengguna (petugas) dapat memilih berbagai macam laporan dan bagan (chart) sesuai dengan kebutuhan informasi Dinas Kesehatan Kabupaten Sleman. Beberapa bagan (chart) yang dibuat merupakan clikable chart yang akan mempermudah pengguna dalam memahami laporan. Dengan adanya prototype sistem ini, berbagai laporan yang dibutuhkan oleh Dinas Kesehatan dapat dibuat dengan lebih cepat dan lebih akurat sehingga dapat digunakan untuk memaksimalkan pengambilan keputusan di lingkungan Dinas Kesehatan Kabupaten Sleman. Prototype sistem yang dibuat dalam penelitian ini diharapkan dapat menjadi melengkapi Sistem Informasi Dinas Kesehatan yang sedang dibangun saat ini dan dapat dipergunakan sementara, sebelum Sistem Informasi tersebut selesai dibangun.

\subsection{Layanan akses berbasis SOA (service oriented architecture)}

Kebutuhan akan integrasi dan interoperabilitas sistem terutama muncul untuk pengambilan keputusan pada aras strategis yang biasanya melibatkan beberapa dinas atau instansi terkait untuk saling bekerjasama. Integrasi dan interoperabilitas ini akan tercapai jika sebuah sistem dapat berkomunikasi dengan sistem yang lainnya tanpa terikat detail teknis seperti perbedaan bahasa pemrograman, sistem operasi, dll, seperti dapat diamati pada gambar 5. Untuk dinas atau instansi lain yang membutuhkan data dari dinas kesehatan, layanan akses berbasis SOA diwujudkan melalui layanan web service yang bersifat loose couple sehingga dapat diakses oleh sistem lain tanpa terhalang perbedaan sistem, bahasa pemrograman, basis data, dll. Menurut Insa (Triono,2005), web service adalah software resource yang melakukan suatu fungsi dan menyediakan jawabannya. Web services dikembangkan dengan mengambil satu set fungsi dan membungkusnya agar layanan yang dilakukan terlihat dan dapat diakses oleh aplikasi software lainnya. Web service dapat meminta layanan dari web service lainnya dan dapat berharap menerima hasil atau tanggapan dari yang meminta. Web service dapat dikenali dan ditingkatkan oleh web service, aplikasi, klien atau agen lainnya. Begitu pula, juga dapat dikombinasikan, dipertukarkan atau disubsitusikan, atau digantikan sambil jalan.

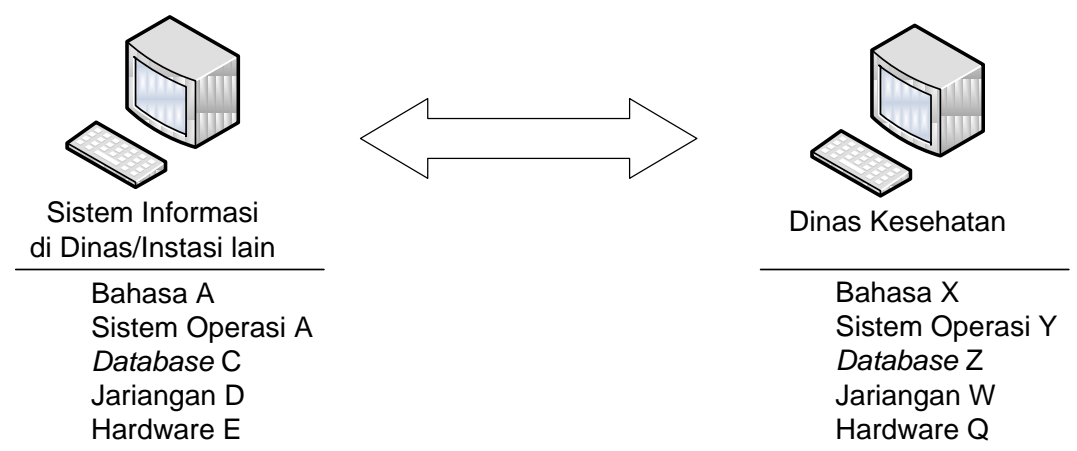

Gambar 5. Interoperabilitas antar sistem 
Seperti dapat diamati pada gambar 6, keadaan saat ini adalah jika dinas atau instansi lain membutuhkan informasi dari dinas kesehatan, maka yang diberikan adalah bentuk excel dari informasi tersebut yang kemudian akan dicetak, hal ini tentu akan menjadi sebuah hambatan ketika dinas/instansi lain membutuhkan data tersebut untuk kemudian diolah lagi, dinas/instansi tersebut harus memasukkan data satu persatu. Kondisi lain memungkinkan data diperoleh dalam bentuk excel yang akan mempermudah dinas/instansi lain dalam mengolah data tersebut lebih lanjut, namun tentu saja hal ini tidak dapat dilakukan secara cepat, karena harus melewati rangkaian birokrasi yang tidak sedikit.

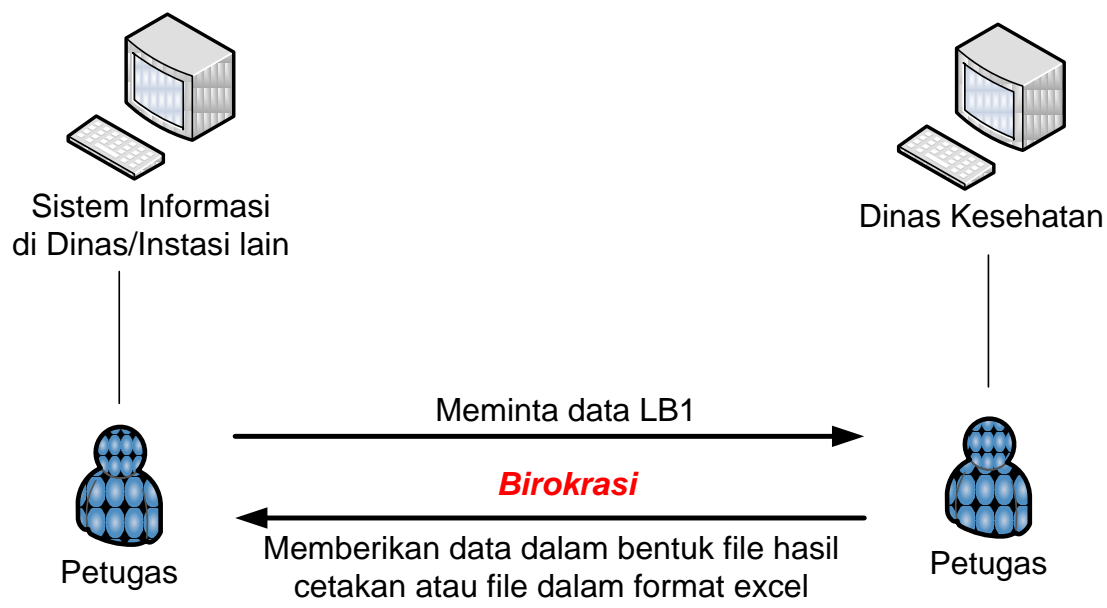

Gambar 6. Gambaran proses permintaan data dari dinas/instansi lain ke dinas kesehatan saat ini

Dengan adanya web service ini maka informasi yang diperoleh dari layanan yang disediakan Dinas Kesehatan Kabupaten Sleman, dapat dimanfaatkan oleh sistem dari dinas/instansi lain dengan lebih cepat dan efisien. Hal tersebut dikarenakan pada SOA komponen utama yang menjadi penghubung antar sistem merupakan suata standar yang berbentuk terbuka seperti XML, WSDL, dan SOAP. Dinas/instansi yang membutuhkan informasi, membaca dokumen WSDL untuk kemudian membuat klien yang dapat mengakses layanan yang disediakan sesuai WSDL yang ada. Informasi yang telah diakses, dapat ditampilkan atau diolah kembali sesuai kebutuhan dinas/instansi yang bersangkutan. Gambar penerapan SOA dalam dinas kesehatan dapat diamati pada gambar 7.

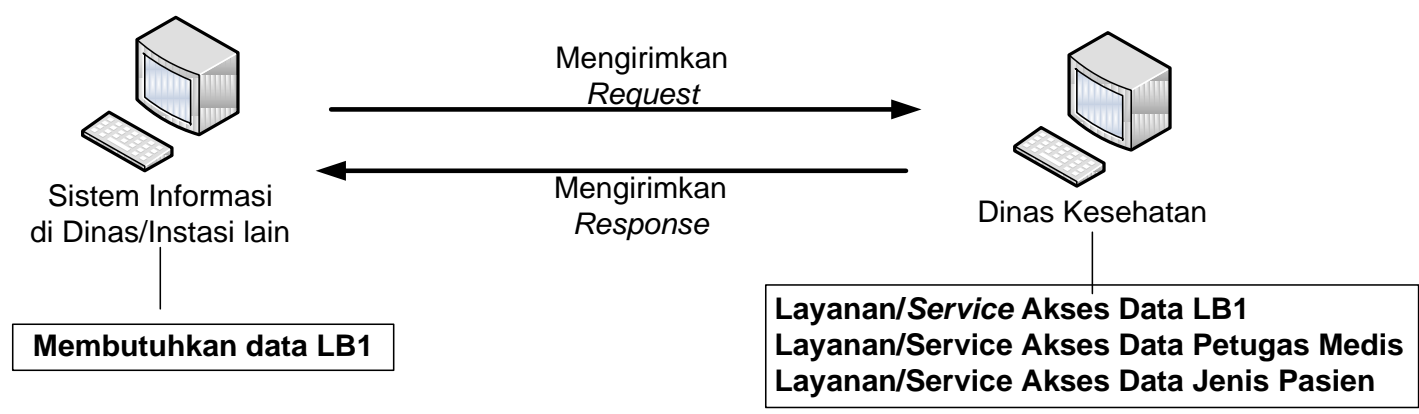

Gambar 7. Implementasi SOA pada dinas kesehatan

Dengan SOA, aplikasi-aplikasi yang dibangun tidak lagi bersifat monolitik, SOA dibentuk dengan merangkai berbagai service modular. Suatu service bisa berupa satu fungsi dari sebuah piranti lunak, seperti misalnya fungsi / layanan untuk mengakses data LB1. Layanan tersebut dapat dieksekusi dengan permintaan sistem apapun, tanpa memandang platform sistem operasinya, bahasa pemrogramannya, maupun lokasi geografisnya.

Dari uraian diatas, dapat disimpulkan sistem dengan kelebihan layanan akses berbasis SOA dibandingkan dengan sistem konvensional yang ada saat ini dapat dilihat di tabel 1 . 
Tabel 1. Perbandingan sistem dengan layanan akses berbasis SOA dan sistem konvensional

\begin{tabular}{|c|c|c|}
\hline No & Sistem dengan layanan akses berbasis SOA & Sistem konvensional yang ada saat ini \\
\hline 1 & $\begin{array}{l}\text { Layanan yang ada memiliki sifat loose couple } \\
\text { sehingga dapat diakses oleh aplikasi yang } \\
\text { berjalan pada platform yang berbeda-beda. }\end{array}$ & $\begin{array}{l}\text { Hanya dapat diakses oleh sistem yang memiliki } \\
\text { platform sama atau sejenis. }\end{array}$ \\
\hline 2 & $\begin{array}{l}\text { Karena kelebihan yang dimiliki pada poin } \\
\text { nomor satu, maka interoperabilitas dapat } \\
\text { tercapai tanpa adanya perubahan platform dari } \\
\text { pihak mana pun yang akan saling } \\
\text { berkomunikasi. } \\
\text { Untuk mengakses layanan yang dimiliki dinas } \\
\text { kesehatan, dinas/instansi lain membuat sebuah } \\
\text { program client untuk mengakses data sesuai } \\
\text { dengan WSDL dari layanan yang akan diakses } \\
\text { dan disesuaikan dengan kebutuhannya masing- } \\
\text { masing. }\end{array}$ & $\begin{array}{l}\text { Ketika dinas / instansi lain yang memiliki } \\
\text { platform berbeda akan mengakses data, maka } \\
\text { yang dilakukan adalah harus melakukan } \\
\text { perubahan / penyesuaian dengan sistem yang } \\
\text { dimiliki dinas kesehatan, atau membuat sebuah } \\
\text { aplikasi yang berfungsi sebagai penghubung } \\
\text { antara kedua pihak. Cara ini tentu saja lebih } \\
\text { rumit, memerlukan biaya lebih besar dan waktu } \\
\text { pembuatan aplikasi lebih lama dibandingan } \\
\text { dengan waktu pembuatan sebuah client untuk } \\
\text { mengakses layanan berbasis SOA. }\end{array}$ \\
\hline 3 & $\begin{array}{l}\text { Waktu yang dibutuhkan untuk memperoleh data } \\
\text { yang dibutuhkan lebih cepat karena tidak harus } \\
\text { melewati birokrasi yang panjang, dan seluruh } \\
\text { ketentuan untuk memperoleh data, telah diatur } \\
\text { dan tercantum dalam WSDL. }\end{array}$ & $\begin{array}{l}\text { Waktu untuk memperoleh data lebih lama } \\
\text { karena harus melewati rangkaian birokrasi } \\
\text { terlebih dahulu. }\end{array}$ \\
\hline 4 & $\begin{array}{l}\text { Data dikirim dalam bentuk XML, yang dapat } \\
\text { langsung ditampilkan atau disimpan dalam } \\
\text { basis data dinas/instasi yang mengakses data } \\
\text { tersebut untuk kemudian diolah kembali sesuai } \\
\text { dengan kebutuhan. }\end{array}$ & $\begin{array}{l}\text { Data yang diperoleh dalam format laporan cetak } \\
\text { atau format excel, sehingga pengolahan lebih } \\
\text { lanjut tidak mudah karena data yang diperoleh } \\
\text { harus di-input kembali atau di konversi ke } \\
\text { format lain, setelah itu baru dapat diolah sesuai } \\
\text { dengan kebutuhan. }\end{array}$ \\
\hline 5 & $\begin{array}{l}\text { Tidak diperlukan petugas dengan ketrampilan } \\
\text { khusus, karena hampir seluruh proses dilakukan } \\
\text { oleh sistem. }\end{array}$ & $\begin{array}{l}\text { Untuk mengolah data yang } \begin{array}{l}\text { diperoleh, } \\
\text { diperlukan petugas } \\
\text { khusus. }\end{array} \\
\text { dengan keterampilan }\end{array}$ \\
\hline
\end{tabular}

\subsection{Pengujian Sistem}

Hasil pengujian rancangan dan implementasi basis data adalah sebagai berikut: (1) Rancangan basis data yang diimplementasikan dapat menyediakan data yang dibutuhkan untuk pembuatan laporan untuk memenuhi kebutuhan informasi dinas kesehatan. (2) Pengujian terhadap struktur tabel dan key yang dibuat dalam rancangan basis data dilakukan dengan pengiriman data dari puskesmas yang hasilnya adalah data dapat masuk dan tersimpan dengan benar dalam basis data yang telah diimplementasikan. (3) Pengujian terhadap relasi yang dibuat dalam rancangan, dilakukan dengan melakukan akses terhadap data dalam basis data yang telah diimplementasikan melalui key yang menghubungkan tabel yang satu dengan tabel yang lainnya. Sebagai contoh, dalam tabel db_puskesmas tercantum kode_kecamatan, yang merupakan foreign key bagi tabel tersebut. Foreign key ini menciptakan sebuah relasi dengan tabel db_kecamatan, dimana kode_kecamatan di dalam tabel ini merupakan primary key-nya. Dengan adanya relasi ini, akan mempermudah pengaksesan data dan meningkatkan efisiensi dalam pengaksesan basis data.

Hasil pengujian prototype aplikasi send data puskesmas adalah sebagai berikut: (1) prototype aplikasi dapat mengirimkan data secara otomatis dari puskesmas ke dinas kesehatan pada jam tertentu sesuai dengan setting yang dilakukan pada windows scheduler. (2) data yang diterima dan masuk ke dalam basis data dinas kesehatan sama dengan data yang dikirim dari puskesmas, hal ini berarti tidak ada data yang hilang (corrupt) selama pengiriman data berlangsung.

Hasil pengujian terhadap laporan dalam prototype sistem untuk dinas kesehatan adalah: (1) Laporan yang dibuat sesuai dengan kebutuhan informasi dinas kesehatan, uji coba prototype sistem juga sudah dilakukan oleh dinas kesehatan. (2) Laporan yang dihasilkan telah dicek 
validitasnya dengan membandingkan hasil laporan yang diperoleh melalui prototype sistem dengan pengaksesan langsung melalui query basis data dan diperoleh hasil yang sama.

Pengujian layanan akses berbasis SOA dilakukan pengujian dengan membuat prototype client yang melakukan request service terhadap layanan yang disediakan, kemudian dilakukan pengecekan terhadap hasil akhir yang diperoleh client. Hasil pengujian adalah: (1) Layanan tersedia dan dapat diakses oleh prototype client. (2) Data yang diakses dapat dimanfaatkan client sesuai dengan kebutuhannya seperti misalnya disimpan ke dalam database client untuk diolah kembali atau langsung ditampilkan ke layar. (3) Data yang diterima client sebagai response dari layanan yang tersedia terhadap request service yang dilakukan, sesuai (sama) dengan data yang dimiliki dinas kesehatan, hal ini berarti tidak ada data yang hilang (corrupt) selama pengiriman data berlangsung.

\subsection{Keunggulan Sistem}

Sistem ini dibangun dengan free software development tools yakni HTML, PHP, Java Script serta ditunjang oleh Cascading Style Sheet dan didukung oleh MySql sebagai database server. Dengan adanya basis data dinas kesehatan, yang memadukan data-data dari puskesmas yang ada di Dinas Kesehatan Kabupaten Sleman, maka akan mempermudah dinas kesehatan dalam memperoleh informasi yang dibutuhkan sehubungan dengan data transaksional puskesmas. Jika sebelumnya untuk mencetak laporan dilakukan secara manual yaitu dengan copy paste satu persatu laporan dari tiap puskesmas kemudian digabungkan dalam satu laporan terpadu, dengan prototype sistem dan rancangan basis data yang dibuat dalam penelitian ini, akan sangat memudahkan dinas kesehatan karena petugas hanya perlu memilih atau memasukkan inputan yang sesuai kemudian laporan dapat diperoleh.

Tabel 2. Komparasi pola lama dan pola baru

\begin{tabular}{|c|c|c|}
\hline Kategori & Pola Lama & Pola Baru \\
\hline \multirow[t]{2}{*}{ Waktu } & $\begin{array}{l}\text { Untuk membuat laporan diperlukan waktu > } \\
30 \text { menit }\end{array}$ & $\begin{array}{l}\text { Untuk membuat laporan diperlukan waktu }< \\
15 \text { menit }\end{array}$ \\
\hline & $\begin{array}{l}\text { Offline, Petugas Puskesmas mengantarkan } \\
\text { laporan puskesmas langsung ke Dinas } \\
\text { Kesehatan }\end{array}$ & $\begin{array}{l}\text { Online, Sistem di puskesmas secara } \\
\text { otomatis mengirimkan data ke dinas } \\
\text { kesehatan }\end{array}$ \\
\hline \multirow[t]{3}{*}{ Proses } & Manual & Otomatis \\
\hline & $\begin{array}{l}\text { Penggabungan laporan dari setiap } \\
\text { puskesmas dilakukan secara manual, } \\
\text { sehingga membutuhkan orang dengan } \\
\text { kemampuan khusus untuk dapat membuat } \\
\text { laporan. }\end{array}$ & $\begin{array}{l}\text { Sistem akan menggabungkan data secara } \\
\text { otomatis ke dalam basis data, dan proses } \\
\text { pembuatan laporan dapat dilakukan oleh } \\
\text { siapa saja (yang memiliki hak akses) }\end{array}$ \\
\hline & $\begin{array}{l}\text { Pengolahan data berulang-ulang di setiap } \\
\text { bagian (divisi di dinas kesehatan) }\end{array}$ & $\begin{array}{l}\text { Laporan yang dibuat dapat digunakan oleh } \\
\text { lebih dari satu divisi. }\end{array}$ \\
\hline Data & $\begin{array}{l}\text { Tidak mendukung integrasi dengan sistem } \\
\text { lainnya }\end{array}$ & $\begin{array}{l}\text { Mendukung Integrasi dengan Sistem } \\
\text { Lainnya. }\end{array}$ \\
\hline
\end{tabular}

Pada penelitian ini, web service sebagai wujud layanan akses berbasis SOA dibangun dengan memanfaatkan NuSOAP. NuSOAP adalah sekumpulan kelas PHP yang memampukan pengguna untuk mengirim dan menerima pesan SOAP yang dikirimkan melalui protocol HTTP Keuntungan yang dapat diperoleh dengan menggunakan NuSOAP adalah karena NuSOAP ditulis murni dengan bahasa PHP dan tidak merupakan PHP extention. Hal ini berarti bahwa setiap pengembang aplikasi dapat tetap menggunakan NuSOAP tanpa harus menambah PHP Extention tertentu pada web server. 


\subsection{Kelemahan Sistem}

Sistem sangat bergantung pada keakuratan data yang diperoleh dari puskesmas, sehingga jika data yang diperoleh banyak yang kosong atau error, maka dapat dipastikan laporan yang dihasilkan oleh sistem tidak akurat dan sesuai dengan kondisi sebenarnya. Kecepatan pengolahan data akan menurun ketika data yang diolah semakin banyak. Selain itu dalam dari segi pengamanan sistem dan layanan web service yang disediakan masih terbatas pada autentifikasi dari password dan username yang dimasukkan oleh pengguna. Faktor keamanan lebih lanjut belum diterapkan dalam sistem karena diluar pembahasan penelitian ini.

\section{Kesimpulan}

Kebutuhan informasi Dinas Kesehatan Kabupaten Sleman yang terkait dengan puskesmas untuk saat ini dipenuhi dari rekap laporan puskesmas yaitu dengan menggabungkan satu persatu laporan yang dikirimkan oleh Puskesmas ke Dinas Kesehatan menggunakan program Excel. Duplikasi data banyak terjadi karena setiap seksi membuat laporannya masingmasing meskipun bersumber dari satu laporan yang sama dari Puskesmas. Dinas Kesehatan Kabupaten Sleman membutuhkan sebuah basis data yang mengintegrasikan data transaksional puskesmas untuk membantu Dinas Kesehatan Kabupaten Sleman dalam memantau kesehatan masyarakat pada umumnya dan secara khusus menyediakan informasi mengenai puskesmas yang dibutuhkan oleh dinas kesehatan. Dalam penelitian ini dibuat sebuah basis data berdasarkan basis data yang dimiliki oleh puskesmas, dan dikembangkan lebih lanjut sesuai dengan kebutuhan dinas kesehatan. Basis data ini memiliki 24 entitas.

Selanjutnya, untuk menjawab kebutuhan informasi Dinas Kesehatan Kabupaten Sleman dalam memantau kesehatan masyarakat, yang dilakukan adalah: (1) Puskesmas mengirimkan data secara otomatis dengan program aplikasi yang telah dibuat dalam penelitian ini. Proses pengiriman dan pengolahan data menjadi lebih mudah, cepat dan efisien karena tidak dilakukan secara manual lagi. (2) Dibuat sebuah prototype sistem bagi Dinas Kesehatan Kabupaten Sleman, dilengkapi dengan berbagai laporan yang mengambil data dari basis data yang telah dibangun. Laporan tersebut antara lain Laporan LB1, Laporan 10 Besar Penyakit, Laporan Tenaga Medis, dll, dan dilengkapi dengan bagan (chart) yang beberapa diantaranya adalah clickable chart.

Agar dinas atau instansi lain yang berkepentingan terhadap informasi (data) yang dimiliki oleh Dinas Kesehatan Kabupaten Sleman dapat memperolehnya dengan mudah, maka dalam penelitian ini dibuat tiga layanan akses data berbasis SOA yang diwujudkan dalam bentuk web service. Layanan tersebut adalah layanan akses LB1, layanan akses data jenis pasien dan layanan akses data petugas medis. Kemudian untuk menguji layanan telah tersedia dan dapat diakses, maka dibuat pula contoh Client untuk masing-masing layanan tersebut.

Kelebihan yang dimiliki oleh layanan akses berbasis SOA adalah: (1) Memiliki sifat loose couple sehingga dapat diakses oleh aplikasi yang berjalan pada platform yang berbedabeda, sehingga interoperabilitas dapat tercapai tanpa adanya perubahan platform dari dinas atau instansi yang akan berkomunikasi atau membutuhkan data dari dinas kesehatan. Hal ini akan menghemat biaya dan meningkatkan efisiensi. (2) Waktu yang diperlukan untuk memperoleh data lebih singkat, karena tidak harus melewati rangkaian birokrasi. (3) Data dikirim dalam bentuk XML, yang akan mempermudah dinas atau instansi yang mengaksesnya untuk pengelolaan lebih lanjut, disesuaikan dengan kebutuhannya.

\section{Saran}

Beberapa saran yang dapat penulis berikan untuk proses pelaksanaan dan pengembangan penelitian selanjutnya, diantaranya adalah: (1) Perbaikan data sumber yaitu data puskesmas. Data sample yang digunakan dari tiga puskesmas masih banyak yang kosong, sehingga laporan yang dihasilkan menjadi terbatas dan kurang akurat. (2) Sumber data dari basis 
data ini terbatas pada data puskesmas, diharapkan peneliti lain dapat mengembangkan basis data untuk data-data Rumah Sakit, Apotik, Dokter Praktek dan Layanan kesehatan yang lain di bawah Dinas Kesehatan Kabupaten Sleman, sehingga tercipta sebuah basis data yang menyeluruh dan dapat menyediakan informasi kesehatan yang terpadu. (3) Fungsi layanan SOA yang diwujudkan masih terbatas pada data yang bersifat public (umum), diharapkan peneliti lain dapat mengimplementasikan SOA pada seluruh bagian termasuk yang bersifat private dengan tetap memperhatikan faktor keamanan data. (4) Diperlukan kebijakan khusus bagi tiga puskesmas yang menggunakan sistem berbeda dengan 21 puskesmas yang dibahas dalam penelitian ini. Selain itu karena diperlukan pula kebijakan mengenai rentang (lama) waktu data disimpan dalam basis data, yang disesuaikan dengan kebutuhan data Dinas Kesehatan Kabupaten Sleman maupun dinas (instansi) lain yang memiliki kebutuhan terkait dengan datadata tersebut.

\section{Referensi}

Achmad, K.A. 2008. Analisis dan Perancangan Sistem Informasi Pelayanan Terpadu berbasis Web service di Pemerintah Kota Pekalongan. Penelitian Tidak Terpublikasi, Yogyakarta: Magister Teknologi Informasi Universitas Gadjah Mada.

Deviana, H. 2007. Penerapan XML Web service untuk Sistem Distribusi Barang (Studi Kasus PT. Apotik Plus Palembang). Penelitian Tidak Terpublikasi. Yogyakarta: Sekolah Pasca Sarjana Ilmu Komputer Universitas Gadjah Mada.

Erl, T. 2005. Service Oriented Architecture: Concepts, Technology, and Design. Indiana: Prentice Hall PTR.

Mawarni, B.E. 2006. Pengembangan XML Web service (Studi Kasus Situs Web Info Lowongan Kerja). Penelitian Tidak Terpublikasi. Yogyakarta: Magister Teknologi Informasi Universitas Gadjah Mada.

Putra, A. 2009. Perancangan Prototype Sistem Informasi Perizinan Penelitian berbasiskan SOA (Service Oriented Architecture). Penelitian Tidak Terpublikasi. Yogyakarta: Magister Teknologi Informasi Universitas Gadjah Mada.

Rasdiyanti. 2008. Pengembangan Database Sarana Pelayanan Kesehatan dan Tenaga Kesehatan Di Dinas Kesehatan Kabupaten Buton. Penelitian Tidak Terpublikasi. Yogyakarta: Program Pasca Sarjana Fakultas Kedokteran Universitas Gadjah Mada.

Robby, O.K., Wardana, F.M. 2009. Analisis dan Perancangan Basis Data untuk Mendukung Aplikasi ERP Education pada Bina Nusantara University (Studi Kasus: Academic Management and Content Preparation). Penelitian Tidak Terpublikasi. Jakarta: Bina Nusantara University.

Setiadi, H., Tejoyuwono, A. 2009. Web service sebagai Solusi Interoperabilitas Antar Aplikasi E-Government, (Online), (http://restama.com/ebook/web-services-sebagai-solusiinteroperabilitas-antar-aplikasi-e-government/, diakses 16 Juli 2009).

Subari. 2008. SOA (Service Oriented Architecture), (Online), (http://subari.blogspot.com/2008/ 03/soa-service-oriented-architecture.html, diakses 12 Juli 2009).

Subroto. 2006. Service Integration: WSI vs SOI, (Online), (http://www.ebdesk.com/library/ marketing/e-Newsletter-2.pdf, diakses 21 April 2009).

Sumanti, E. 2008. Interoperabilitas dalam Integrasi Data Pemerintah (Kasus Pada Dinas Kesehatan dan Kependudukan Kota Mataram). Penelitian Tidak Terpublikasi. Yogyakarta: Sekolah Pasca Sarjana Universitas Gadjah Mada.

Triono, S. 2005. Penerapan XML Web Service dalam Sistem Informasi Akademik. Penelitian Tidak Terpublikasi. Yogyakarta: Sekolah Pasca Sarjana Universitas Gadjah Mada. 